\title{
Preliminary results from case-control study confirm Zika virus causes microcephaly
}

\author{
Susan Mayor
}

London

Zika virus in utero is causally associated with microcephaly in infants, showed preliminary results from the first case-control study to investigate whether Zika virus infection during pregnancy can result in microcephaly. ${ }^{1}$

The Brazilian Ministry of Health requested that a study be undertaken to investigate the causes of the microcephaly epidemic after declaring it a national public health emergency in November 2015. It was assumed that the relation between Zika virus and microcephaly was causal, but this had previously not been tested in studies with appropriate control groups.

The new study, published in Lancet Infectious Diseases, prospectively recruited all 32 infants born with microcephaly in eight public hospitals in Recife, Brazil, between 15 January and 2 May 2016. Each baby was matched with two controls-babies without microcephaly born the morning after the birth of each case in one of the eight hospitals taking part in the study.

All mothers and babies were tested for Zika virus and Zika virus antibodies in blood and cerebrospinal fluid. Infants with microcephaly had their brain circumference measured, and most underwent brain imaging.

The results showed that $24(80 \%)$ of 30 mothers of babies with microcephaly had Zika virus infection compared with $39(64 \%)$ of 61 mothers of controls $(\mathrm{P}=0.12)$, which the authors said reflected the rapid spread of Zika virus infection in the region.
However, lead author of the study, Thalia Velho Barreto de Araújo, from Federal University of Pernambuco, in Recife, Brazil, said, "When we compared laboratory confirmed Zika virus infection in newborns with and without microcephaly, we found that about half of the cases with microcephaly had laboratory confirmed Zika virus infection, compared to none of the healthy controls." Thirteen of the 32 babies with microcephaly (41\%) had laboratory confirmed Zika virus infection, but none of the controls did.

The researchers noted, "This preliminary analysis shows a strong association between microcephaly and laboratory confirmation of Zika virus infection . . . in cerebrospinal fluid or serum of neonates." They said that the risk was high in cases with brain abnormalities detected by imaging but was also present in babies with microcephaly without brain abnormalities.

Further results from the full study of 200 cases and 400 controls will help to quantify the risk more precisely, the authors concluded.

Araúio TV, Rodrigues LC, Ximenes RA, et al. Association between Zika virus infection and microcephaly in Brazil, January to May, 2016: preliminary report of a case-control study. Lancet Infect Dis 2016. doi:10.1016/S1473-3099(16)30318-8.

Published by the BMJ Publishing Group Limited. For permission to use (where not already granted under a licence) please go to http://group.bmj.com/group/rights-licensing/ permissions 